Journal of Animal and Veterinary Advances 9 (24): 3070-3076, 2010

ISSN: $1680-5593$

(C) Medwell Journals, 2010

\title{
Effect of Chemical Treatment of Rice Straw on Rumen Fermentation Characteristic, Anaerobic Fungal Diversity in vitro
}

\author{
Pichad Khejornsart and Metha Wanapat \\ Tropical Feed Resources Research and Development Center (TROFREC), \\ Department of Animal Science, Faculty of Agriculture, \\ Khon Kaen University, 40002, Khon Kaen, Thailand
}

\begin{abstract}
In vitro gas production was measured to investigate associative effects of untreated and chemically treated Rice Straw (RS). The RS was treated with $\mathrm{NaOH}$, urea or lime and evaluated the nutritive value of treated rice straw using in vitro gas production. Cumulative gas production was recorded at $2,4,6,8,12,36,48,72$ and $96 \mathrm{~h}$ of incubation and the analyzed to describe the kinetics of gas production. Total nucleic acid was extracted from ruminal content in vial of each treatment and contribution of fungal population was estimated by using PCR-DGGE technique. It was found that the treatment with $\mathrm{NaOH}$, urea and lime increased $(\mathrm{p}<0.05)$ gas production at $24 \mathrm{~h}$, potential GP and rate constant of GP were highest for $\mathrm{NaOH}$, follow by $2 \%$ urea $+2 \%$ lime, $3 \%$ urea, $3 \%$ lime, $3.5 \%$ urea $+3.5 \%$ lime and lowest for $5 \%$ urea treated rice straw $(\mathrm{p}<0.05)$. Ammonia nitrogen was increased belong to the increase of urea level treating rice straw. It was higher in $5 \%$ urea treatment and $3 \%$ urea-lime treatment and $2 \%$ urea-lime treatment. Total VFA and acetate and propionate concentrations were higher for $3 \%$ urea and $2 \%$ urea-lime as compared with other treatments $(\mathrm{p}<0.05)$. All treated rice straw shown similar in diversity of fungi except $2 \%$ sodium treated rice straw. Other treated rice straw was found similar in the diversity of fungi with 6 bands per each lane. The results from this study suggest that $2 \%$ urea plus lime treated rice straw can use as good roughage for ruminants to improve rumen fermentation, digestibility and low cost and treatments rice straw were shift the number species of rumen fungi.
\end{abstract}

$\underline{\text { Key words: Chemical treatment, rice straw, ruminal fermentation, anaerobic fungi, diversity, treatment rice }}$

\section{INTRODUCTION}

Ruminant production in many tropical regions is limited by poor-quality diets that are often deficient in nitrogen and have low digestibility which can be limit the number of rumen microbes (Orskov, 1994). Improvement in the nutrient utilization of low-quality roughages would substantially improve ruminant productivity and milk production (Wanapat, 1999). There is rising interest in the use of feeds with a high content of rapidly degradable fiber as supplements to ruminants consuming poorquality forage diets. Chemical treatment methods were conducted use to improve nutritive value of rice straw (Wanapat et al., 1985, 1986; Liu et al., 1995). The in vitro gas production technique has been used as a measure of ruminal degradation of feeds (Menke and Steingass, 1988; Blummel et al., 1997; Getachew et al., 1998) and as an indicator of digestible DMI and growth rate of cattle fed cereal straws (Blummel and Orskov, 1993). This technique also has potential to investigate associative effects between feeds. Fungi play an important synergistic role in the ruminal digestion of fiber by physical and chemical breakdown the lignified stem tissue which high potent fibrolytic enzymes for fiber degradation (Theodorou et al., 1992; Trinci et al., 1994).

This allows the rumen bacteria easier access to the plant stem and the digestible portions of the plant. Traditional cultivating and enumerating methods such as microscopy and colony counts in early studies are based on the use of the classic anaerobic culture techniques (Theodorou et al., 1990). Recently with the advent of gene based technology, more sensitive, accurate and cultivateindependent molecular detection methods such as hybridization probes and quantitative Polymerase Chain Reaction (qPCR) have been developed. Denman and McSweeney (2006) have been real-time PCR to monitoring diurnal patterns of populations of rumen fungi, Ruminococcus flavefaciens and Fibrobacter succinogenes within cattle. Moreover, Tajima et al. (2001) and Wanapat and Cherdthong (2009) have shown that real-time PCR can be used successfully on samples

Corresponding Author: Metha Wanapat, Tropical Feed Resources Research and Development Center (TROFREC), Department of Animal Science, Faculty of Agriculture, Khon Kaen University, 40002, Khon Kaen, Thailand 
extracted from rumen contents to monitor population shifts due to diet changes. Although, in previous studies (Liu et al., 2005; Wang et al., 2007) as resulted by electron microscopy, chemical treatment changed histological structures of rice straw and increased colonization of the RS by rumen bacteria and fungi. However, it is limit to quantify microbial population from the electron microscopical pictures. Therefore, the objective of the present study was to determine the associative effects between untreated and chemically treated rice straw using the gas production technique on fermentation and populations diversity of rumen fungi.

\section{MATERIALS AND METHODS}

Rice straw treatments and chemical analysis: Rice straw was obtained from the paddy field of farmer in Khon Kaen, Thailand. Rice straw was manually chopped to $5 \mathrm{~cm}$ length and treated with $30 \mathrm{~g} \mathrm{~kg}^{-1}$ urea (3 URS), $50 \mathrm{~g}$ $\mathrm{kg}^{-1}$ urea (5 URS), $20 \mathrm{~g} \mathrm{~kg}^{-1}$ urea $+20 \mathrm{~g} \mathrm{~kg}^{-1}$ lime (2ULRS), $35 \mathrm{~g} \mathrm{~kg}^{-1}$ urea $+35 \mathrm{~g} \mathrm{~kg}^{-1}$ lime (3.5 ULRS), $20 \mathrm{~g} \mathrm{~kg}^{-1} \mathrm{NaOH}$ and $30 \mathrm{~g} \mathrm{~kg}^{-1}$ lime, respectively. The amount of water added was $700 \mathrm{~mL} \mathrm{~kg}^{-1} \mathrm{RS}$. The treated RS were prepared in black plastic bags at room temperature for 21 days. After completion of the treatment, the feeds were dried $\left(60^{\circ} \mathrm{C}\right)$ and milled through a $1 \mathrm{~mm}$ screen prior to chemical analyses and in vitro gas production measurements. Determination of Kjeldahl N (method 954.01 and ash method 942.05) contents was performed according to AOAC (1990). Crude Protein (CP) was calculated as KjeldahIN $\times 6.25$. Neutral Detergent Fiber $(\mathrm{NDF})$ and Acid Detergent Fiber (ADF) were determined by the method of
Van Soest et al. (1991). Hemicellulose was calculated as NDF-ADF. The chemical composition of the straws is shown in Table 1.

In vitro gas production: In vitro Gas Production (GP) will measured in triplicate at $2,4,6,8,12,36,48,72$ and $96 \mathrm{~h}$ using cumulative gas technique (Menke and Steingass, 1988). Rumen fluids were collected from two buffaloes (369 $\pm 28 \mathrm{~kg}$ BW) fed twice daily on a rice straw ad libitum and concentrates $(0.5 \% \mathrm{BW})$ before morning feeding and strained through two layers of cheesecloth into a pre-warmed and insulated bottle at $39^{\circ} \mathrm{C}$.

All laboratory handling of rumen fluid were carried out under continuous flushing with $\mathrm{CO}_{2}$. Inoculation were done in triplicate with $10 \mathrm{~mL}$ rumen fluid injected into $60 \mathrm{~mL}$ bottle containing $30 \mathrm{~mL}$ of buffered medium and $0.2 \mathrm{~g}$ dry substrate at $39^{\circ} \mathrm{C}$. In each incubation run, three blanks will included simultaneously correcting the GP values for gas release from endogenous substrates and other nine bottles for each treatment was included simultaneously to determine dynamic fermentation variables and rumen microbes (Table 2).

Collection samples and analysis: The three bottles incubated for each treatment were withdrawn from the incubator at 6,12 and $24 \mathrm{~h}$ of incubation, respectively. The fermentation was stopped by swirling the flasks in ice water. About $30 \mathrm{~mL}$ of mixed fermentation medium was used for analysis of ammonia nitrogen and Volatile Fatty Acids (VFA). The remaining contents were collected for quantitative analysis of microbial populations.

Table 1: Chemical composition of treated rice straw and untreated rice straw used for in vitro trial (DM basis)

\begin{tabular}{|c|c|c|c|c|c|c|c|}
\hline \multirow[b]{2}{*}{ Nutrients (\%DM) } & \multicolumn{7}{|c|}{ Treated rice with } \\
\hline & None & 3URS & 5URS & 2ULRS & 3.5ULRS & 2SRS & 3LRS \\
\hline $\mathrm{DM}$ & 96.5 & 94.2 & 93.9 & 96.6 & 95.9 & 94.70 & 97.6 \\
\hline $\mathrm{OM}$ & 89.5 & 91.2 & 92.6 & 84.3 & 78.6 & 82.80 & 77.4 \\
\hline $\mathrm{CP}$ & 2.2 & 7.9 & 11.2 & 5.8 & 8.5 & 4.00 & 3.8 \\
\hline $\mathrm{NDF}$ & 56.6 & 54.8 & 44.7 & 51.4 & 36.8 & 42.20 & 47.5 \\
\hline $\mathrm{ADF}$ & 38.0 & 31.6 & 29.7 & 34.9 & 25.4 & 35.00 & 34.9 \\
\hline Lignin & 3.7 & 3.0 & 3.3 & 4.7 & 4.0 & 3.90 & 5.0 \\
\hline Hemicellulose & 18.6 & 23.3 & 15.0 & 16.5 & 11.4 & 7.20 & 12.6 \\
\hline Ash & 10.5 & 8.8 & 7.4 & 15.7 & 21.4 & 17.20 & 22.6 \\
\hline
\end{tabular}

${ }^{1} \mathrm{DM}=$ Dry Matter, $\mathrm{CP}=$ Crude Protein, $\mathrm{OM}=$ Organic Matter, $\mathrm{NDF}=$ Neutral Detergent Fiber, $\mathrm{ADF}=$ Acid Detergent Fiber

Table 2: Effect of treated rice straw and urea in concentrate on gas production ( $\mathrm{mL} / 0.2 \mathrm{~g}$ substrate) and fermentation characteristic from in vitro Treated rice straw with

\begin{tabular}{|c|c|c|c|c|c|c|c|c|}
\hline \multirow[b]{2}{*}{ Items } & & & & & & & & \\
\hline & None & 3URS & 5URS & 2ULRS & 3.5ULRS & 2SRS & 3LRS & SEM \\
\hline \multicolumn{9}{|l|}{ GP parameters } \\
\hline Potential GP $\left(\mathrm{mLg}^{-1}\right)$ & $51.69^{b}$ & $63.44^{\mathrm{a}}$ & $46.37^{\mathrm{bc}}$ & $61.91^{\mathrm{a}}$ & $46.11^{b c}$ & $53.16^{b}$ & $53.15^{b}$ & 2.570 \\
\hline Rate of GP (mL h $\left.{ }^{-1}\right)$ & $0.04^{b}$ & $0.04^{b}$ & $0.03^{b}$ & $0.05^{\mathrm{ab}}$ & $0.04^{b}$ & $0.07^{\mathrm{a}}$ & $0.04^{b}$ & 0.005 \\
\hline Lag time (h) & $1.35^{b}$ & $2.35^{\mathrm{a}}$ & $1.27^{b}$ & $2.11^{\mathrm{a}}$ & $2.14^{\mathrm{a}}$ & $2.42^{\mathrm{a}}$ & $1.35^{b}$ & 0.190 \\
\hline $\mathrm{NH}_{3}-\mathrm{N}\left(\mathrm{mg} \mathrm{dL}^{-1}\right)$ & $15.20^{\circ}$ & $19.80^{b}$ & $29.00^{\mathrm{a}}$ & $18.30^{b}$ & $20.60^{b}$ & $12.30^{c}$ & $14.00^{c}$ & 2.100 \\
\hline Total VFA $\left(\mathrm{mmol} \mathrm{L}^{-1}\right)$ & $42.60^{b}$ & $87.40^{\mathrm{a}}$ & $41.30^{b}$ & $84.30^{\mathrm{a}}$ & $52.30^{b}$ & $50.70^{\mathrm{b}}$ & $39.10^{c}$ & 6.150 \\
\hline Acetate, $\mathrm{C} 2$ & $27.30^{b}$ & $53.90^{\mathrm{a}}$ & $25.80^{b}$ & $57.90^{\mathrm{a}}$ & $36.70^{b}$ & $36.20^{b}$ & $26.50^{b}$ & 4.500 \\
\hline Propionate, $\mathrm{C} 3$ & $6.20^{b}$ & $12.00^{\mathrm{a}}$ & $6.70^{b}$ & $13.90^{\mathrm{a}}$ & $8.70^{b}$ & $10.60^{\mathrm{a}}$ & $6.40^{b}$ & 1.010 \\
\hline Butyrate, C4 & 3.10 & 4.60 & $4.00^{\mathrm{a}}$ & $3.90^{\mathrm{a}}$ & $4.30^{b}$ & $5.10^{\mathrm{a}}$ & $2.60^{\mathrm{b}}$ & 0.640 \\
\hline $\mathrm{C} 2: \mathrm{C} 3$ & $4.40^{\mathrm{a}}$ & $4.40^{\mathrm{a}}$ & $3.80^{b}$ & $4.20^{\mathrm{a}}$ & $4.20^{\mathrm{a}}$ & $3.40^{\mathrm{b}}$ & $4.10^{\mathrm{a}}$ & 0.190 \\
\hline
\end{tabular}

${ }^{1} \mathrm{DM}=$ Dry Matter, $\mathrm{CP}=$ Crude Protein, $\mathrm{OM}=$ Organic Matter, NDF = Neutral Detergent FIber, ADF $=$ Acid Detergent Fiber 
Fermentation variables such as ammonia nitrogen and VFA were determined, concentration of $\mathrm{NH}_{3}-\mathrm{N}$ was determined by using micro Kjeldahl methods (AOAC, 1990) and VFA concentration was determined using HPLC (instruments: controller water model $600 \mathrm{E}$; water model 484 UV detector; Novapak $\mathrm{C}_{18}$ column; column size $4 \times 150$ $\mathrm{mm}$; mobile phase $10 \mathrm{mmol} \mathrm{L} \mathrm{L}^{-1} \mathrm{H}_{4} \mathrm{PO}_{4}$ (pH 2.5)) (Samuel et al., 1997).

DNA isolation and amplication: Rumen digesta and content from vial bottle were collected $1 \mathrm{~mL}$ for DNA extraction by the repeated bead beating plus column ( $\mathrm{RBB}+\mathrm{C}$ ) method (Yu and Morrison, 2004). Genomic DNA was treated with RNase A and Proteinase $\mathrm{K}$ and the DNA was purified using columns from the QIAGEN DNA Mini Kit (QIAGEN, Valencia, CA). For DGGE, primer MN100 (TCCTACCCTTTGTGAATTTG) and MNGM2C (CTGCGTTCTTCATCGTTGCGCGCCCGCCGCGCGCGG CGGGCGGGGCGGGGGCACGGGGGG) were used as described by Nicholson et al. (2010). PCR reactions was adapted according to Nicholson et al. (2010) that contained $2.5 \mathrm{~mL} 10 \times$ buffer, $2.5 \mathrm{~mL} \mathrm{1/25}$ dilution genomic DNA, $0.5 \mathrm{~mL}$ dNTP mix (10 mM each), $0.5 \mathrm{~mL}$. Advantage 2 polymerase mix (FastStart Taq, Roche), 10 picomoles of each primer and molecular biology grade water to make a final reaction volume of $25 \mathrm{~mL}$. Thermal cycling consisted of $95^{\circ} \mathrm{C}$ for $5 \mathrm{~min}$ followed by 20 cycles of: $95^{\circ} \mathrm{C}$ for $30 \mathrm{sec}, 68^{\circ} \mathrm{C}\left(-0.5^{\circ} \mathrm{C}\right.$ each cycle $)$ for $30 \mathrm{sec}, 72^{\circ} \mathrm{C}$ for $30 \mathrm{sec}$; then 12 cycles of: $95^{\circ} \mathrm{C}$ for $30 \mathrm{sec}, 58^{\circ} \mathrm{C}$ for $30 \mathrm{sec}, 72^{\circ} \mathrm{C}$ for $30 \mathrm{sec}$; followed by $72^{\circ} \mathrm{C}$ for $6 \mathrm{~min}$. Successful amplification was verified by electrophoresis of the reaction mixture on a $1.5 \%(\mathrm{w} / \mathrm{v})$ agarose gel.

Electrophoresis and gel analyses: DGGE was performed using a D-Code Universal Mutation Detection System (Bio-Rad Laboratories Ltd., UK) with $16 \times 16 \mathrm{~cm}$ glass plates separated by $1 \mathrm{~mm}$ spacers. DGGE was performed to separate PCR amplicon, $12 \mu \mathrm{L}$ of PCR product and dye mix was loaded in each sample well (16-well comb) and using $10 \%$ polyacrylamide gel (37.5:1 acrylamidebisacrylamide ratio) containing a gradient of $15-30 \%$ denaturant where $100 \%$ denaturant solution contained 7 $\mathrm{M}$ urea and $40 \%(\mathrm{v} / \mathrm{v})$ formamide. Gels were placed in electrophoresis tank using $0.5 \times \mathrm{TAE}$ ( $20 \mathrm{mM}$ Tris; $\mathrm{pH} 7.4$, $10 \mathrm{mM}$ sodium acetate, $0.5 \mathrm{M}$ EDTA) running buffer heated to $60^{\circ} \mathrm{C}$. Optimized conditions for products amplified with MN100 and MNGM2C were $15-30 \%$ denaturant electrophoresed at $200 \mathrm{~V}$ for $5 \mathrm{~min}$ and $85 \mathrm{~V}$ for $8 \mathrm{~h}$ in running buffer heated to $60^{\circ} \mathrm{C}$. After electrophoresis DGGE gel was stained with SYBR ${ }^{\circledR}$ Gold (Molecular Probes Inc., USA) and then gel images were captured using Photo documentation (Vilber Lourmat, France).
The gel images were then imported into the software package fingerprinting (Bio-Rad UK Ltd.) for analysis (Fingerprint Types and Cluster Analysis modules). Cluster analysis was performed using the Dice similarity coefficient with a position tolerance of $0.5 \%$ and an optimization parameter of $1 \%$ with clusters constructed using the unweighted pair-wise grouping with mathematical averages method.

Calculations and statistical analysis: To describe the dynamics of GP over time, the following equation (Orskov and McDonald, 1979) was chosen: $G P=a+b$ (1-e-ct) where GP = cumulative GP $(\mathrm{mL}),(\mathrm{a}+\mathrm{b})=$ potential $\mathrm{GP}\left(\mathrm{mL} \mathrm{g}^{-1}\right), \mathrm{c}=$ rate of $\mathrm{GP}\left(\mathrm{mL} \mathrm{h}^{-1}\right)$ and $\mathrm{a}, \mathrm{b}$ and $\mathrm{c}$ are constants. The a value is the intercept of GP curve. If the a value was negative as noted by Wilman et al. (1996), indicating a lag time before rapid degradation began, the length of the lag time was estimated as $(1 / \mathrm{c}) \ln [\mathrm{b} /(\mathrm{a}+\mathrm{b})]$ (McDonald, 1981). For the positive a value, the lag time was designated as zero.

The effects of chemical treatments on rumen GP and fermentation parameters were analyzed by the General Linear Model (GLM) procedure of SAS (1998). The differences of means for the treatments were tested by using Duncan's new multiple range test.

\section{RESULTS AND DISCUSSION}

Chemical composition: Chemical composition of feeds used for in vitro trial is shown in Table 1. All chemical treated rice straw increased in crude protein, the increase sequence was due to urea level added to rice straw, from $5 \%$ urea and followed by $3.5 \%$ urea and $3 \%$ urea. Sodium hydroxide and lime treated rice straw had low crude protein content. Chemical treated rice straw also resulted in reduces $\mathrm{NDF}$ and $\mathrm{ADF}$ of rice straw as reduce hemicellulose content.

Gas production and fermentation characteristic: Figure 1 shows the cumulative gas production for each substrate treatment. All gas volumes showed increased as fermentation time interval proceeded from $0-96 \mathrm{~h}$ after incubation. The cumulative GP at all incubation times was higher from treated RS than from untreated. Potential gas production was highest in 3\% urea treatment and followed by $2 \%$ urea- $2 \%$ lime treatment (Table 1 ). It was resulted in highest production of gas. Before $24 \mathrm{~h}$ incubation, gas were produced highest in $2 \%$ sodium hydroxide, however, after $24 \mathrm{~h}$ incubation it was reduced as compared with T2 and T4 but it was still higher than other one. Sodium hydroxide teatment showed highest in rate of gas 


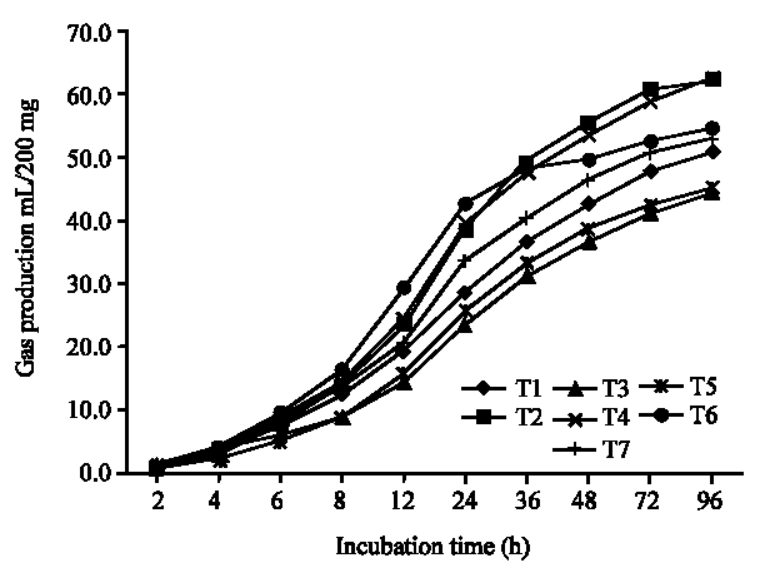

Fig. 1: Cumulative gas production of T1: untreated (RS), T2: 3\% Urea treated Rice Straw (3URS), T3: 5\% Urea treated Rice Straw (5URS), T4: 2\% Urea-2\% Lime treated Rice Straw (2ULRS), T5: 3.5\% Urea3.5\% Lime treated Rice Straw (3.5ULRS), T6: 2\% Sodium hydroxide treated rice straw (2SRS) and T7: 3\% Lime treated Rice Straw (3LRS) at different of incubation time

production $\left(0.07 \mathrm{~mL} \mathrm{~h}^{-1}\right)$. Under this study, 5\% urea treatment and $3.5 \%$ urea- $-3.5 \%$ lime treatment were resulted lower gas production as compared with other one.

Ammonia nitrogen was increased belong to the increase of urea level treating rice straw. It was higher in $5 \%$ urea treatment and 3\% urea-lime treatment and $2 \%$ urea-lime treatment. Total VFA and acetate and propionate concentrations were higher for $3 \%$ urea and $2 \%$ urea-lime as compared with other treatments $(\mathrm{p}<0.05)$. Butyrate showed no significant difference among straws ( $>0.05$ ). Both treated and untreated straws maintained a typical roughage type of fermentation with a high proportion of acetate.

Rumen microbial population diversity: Figure 2 shows fungi diversity of samples from gas production technique. The electrophoresis gel indicates that there are different appearance bands in untreated rice straw and treated rice straw (Fig. 3). UPGMA method estimated the similar species in untreated rice straw with treated rice straw was about $72 \%$. All treated rice straw shown similar in diversity of fungi except $2 \%$ sodium treated rice straw. This treatment was shift the number species of rumen fungi. Other treated rice straw was found similar in the diversity of fungi with 6 bands per each lane. The chemical composition was shown lower fiber contain and increased protein.

Crude protein contents were significantly increased by treatments containing $\mathrm{N}$-sources, especially by urea as reported by Wanapat et al. (1985) urea treated rice straw was increased protein 6-7 time higher than untreated straw. Moreover as pointed by Van Soest (2006) treatments ammonia, urea and urine produced changes in the fiber and lignin fractions, with small decrease (2-4\%) in NDF and increases in ADF (3\% and lignin 20-50\%), leading to decrease in the NDF-ADF difference (10-20\%). Kennedy et al. (1999) found that isolated NDF was fermented more readily than the cell walls in intact grasses. Under this study, it was shown lower fiber content in $\mathrm{NaOH}$ treated rice straw. The modes of action of chemical treatments have been described by Klopferstein (1978) that a chemical treatment solubilizes some of hemicelluloses while cellulose remains unchanged.

As reported previously (Wanapat et al., 1986; Trach et al., 2001; Liu et al., 2002; Fadel Elseed et al., 2003; Wanapat et al., 2009), chemical treatments increased digestibility of low-quality rice straw and sodium hydroxide treatment had stronger effect on dissolved cell wall than urea and calcium hydroxide. Thus, sodium hydroxide had high gas rate. However, after $24 \mathrm{~h}$ incubation, treatment with sodium hydroxide was reduced if compared with $3 \%$ urea and $2 \%$ urea-lime treated rice straw. It could be explained by the amount of supplement nitrogen which need for microbes rumen. Higher nitrogen content from $3 \%$ urea treatment and $2 \%$ urealime treatment contributed in increased ammonia nitrogen concentration in culture media. The 5\% urea and 3.5\% urea-lime treatment was shown increase in rumen microbes and digestibility in in vivo technique (Wanapat et al., 1986; Trach et al., 2001) however, in the present study using in vitro gas production technique in high level of urea treat rice straw not show higher gas production. A comparative study of chemical treatment methods was conducted by Wanapat et al. $(1985,1986)$, it was found that based on digestibility and energy utilization studies that the most efficient treatments ranked from highest to lowest were; wet $\mathrm{NaOH}$ treatement, dry $\mathrm{NaOH}$ treatement, anhydrous $\mathrm{NH}_{3}$ treatment, urea treatment and untreated rice straw. In addition, the use of ammonia bicarbonate treatment has been shown to increase the fiber digestion kinetics, nutrient digestibility and nitrogen balance (Liu et al., 1995). An increase in total VFA of treated RS except lime treatment may be due to an increased fermentation rate in vitro that was reflected by the increased gas production. Microbial crude protein concentration in treated RS was higher than in untreated $\mathrm{RS}$, consistent with the increase in gas production and VFA concentration. Both rice straw and treated rice straw produced high rate of acetate, propionate concentration and was increased linearly with treatment high in rate of gas production. Hart and Wanapat (1992) reported that urea-ammonia treatment (5\%) was increased intake of digestible organic matter up to 46 and $24 \%$ of ruminal VFA higher than untreated rice 




Fig. 2: Negative image of SYBR ${ }^{\circledR}$ Gold stained denaturing gradient gel electrophoresis separation pattern of eight PCR samples from buffalo in which the rumen fungi ITS1 amplicon using MN100 and MNGM2C primers (T1 = RS, $\mathrm{T} 2=\mathrm{RS}+4 \%$ urea, $\mathrm{T} 3=\mathrm{ULRS}+0 \%$ urea and $\mathrm{T} 4=\mathrm{ULRS}+4 \%$ urea) are shown

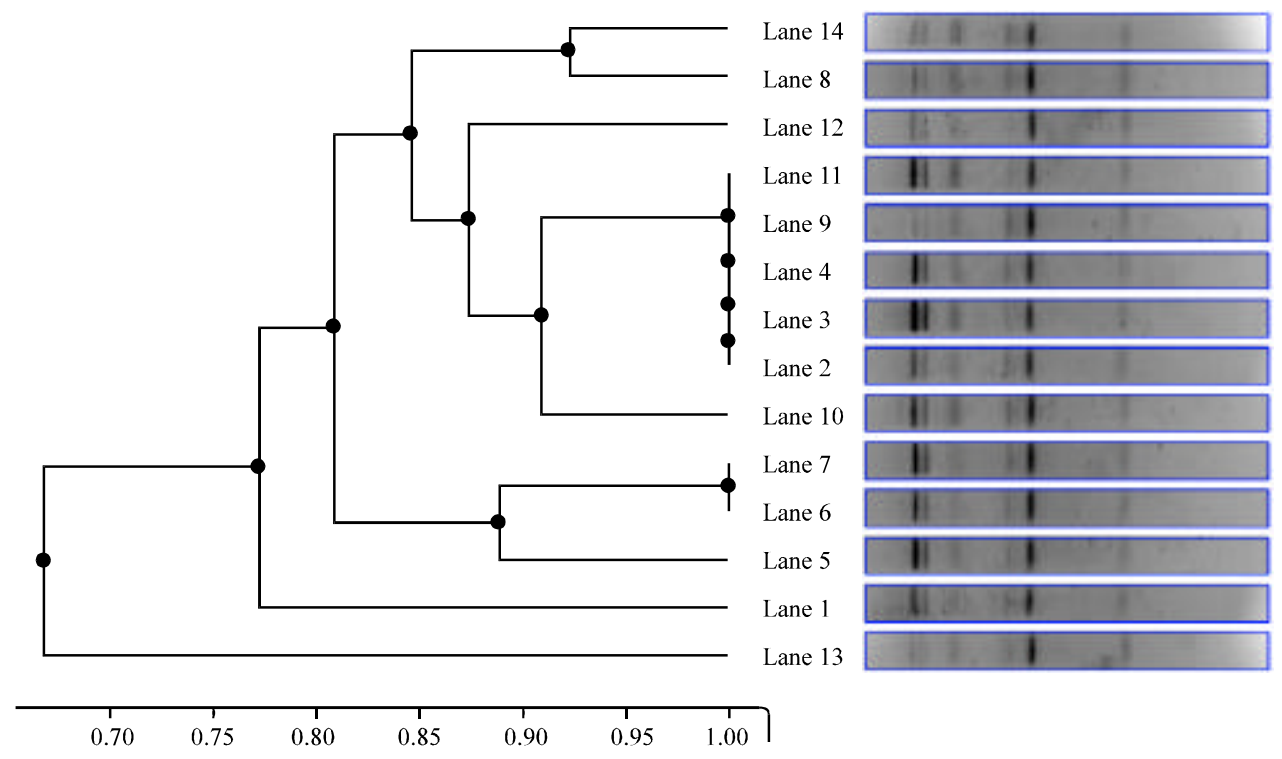

Fig. 3: The analysis of denaturing gradient gel electrophoresis of anaerobic fungi ITS1 amplicons from gas production technique sampled using UPGMA

straw. Orskov et al. (1980) suggested that the optimum amount of $\mathrm{NaOH}$ required differed between cereals, being about $3.0-3.5 \%$ for barley, $4.5-5.0 \%$ for oats and $2.5-3.0 \%$ for maize and wheat.

The difference in diversity of fungi could be explained by different substrate occurred. Fungi strongly developed in fiber substrates and slower in soft or leave substrate.

This reason could explain the difference in diversity of rumen fungi between untreated rice straw and chemical treated rice straw which resulted in making soft rice straw. Among DNA samples, take among treated rice straw.
Sodium hydroxide shifted the diversity of rumen fungi appeared in other dietary treatments. It could explain by the strong effect of sodium on structural carbohydrate of straw, strongly dissolved in cell wall. Thus reduced the activities of fungi and resulted in disappearance or changing in natural diversity of fungi.

\section{CONCLUSION}

Based on this experiment it could be concluded that chemical treated rice straw increased gas production. 
Treating rice straw with $3 \%$ urea or $2 \%$ urea-lime was resulted in high gas production and high in rate of VFA, acetate and propionate concentration. Treating rice straw slightly shifted fungi diversity as compared with untreated. Using sodium hydroxide should be considered in term of changing fungi diversity but with saving in cost and reduce urea amount.

\section{RECOMMENDATIONS}

This experiment also suggested that $2 \%$ urea plus lime treated rice straw can use as good roughage for ruminants to improve rumen fermentation, digestibility and low cost. Therefore, further experiment should be conducted to study and compare effect of $2 \%$ urea-lime treated rice straw on in feeding trials with other dietary treatments.

\section{ACKNOWLEDGEMENTS}

The researchers would like to express their most sincere gratitude and appreciation to the Commission on Higher Education, Thailand under the Strategic Scholarships for Frontier Research Network program and the Tropical Feed Resources Research and Development Center (Trofrec), Department of Animal Science, Faculty of Agriculture, Khon Kaen University, Thailand for their financial support of research and the use of research facilities. The researches also acknowledge Agricultural Biotechnology Research Center, Khon Kaen University for real-time PCR analysis and for technical support.

\section{REFERENCES}

AOAC, 1990. Official Methods of Analysis. 15th Edn., Association of Official Analytical Chemists, Washington DC. USA., pp: 200-210.

Blummel, M. and E.R. Orskov, 1993. Comparison of in vitro gas production and nylon bag degradability of roughages in prediction of feed intake in cattle. Anim. Feed Sci. Technol., 40: 109-119.

Blummel, M., H.P.S. Makkar and K. Becker, 1997. In vitro gas production: A technique revisited. J. Anim. Physiol. Anim. Nutr., 77: 24-34.

Denman, S.E. and C.S. McSweeney, 2006. Development of a real-time PCR assay for monitoring anaerobic fungal and cellulolytic bacterial populations with in the rumen. FEMS Microbiol. Ecol., 58: 572-582.
Fadel Elseed, A.M.A., J. Sekine, M. Hishinuma and K. Hamana, 2003. Effects of ammonia, urea plus calcium hydroxide and animal urine treatments on chemical composition and in sacco degradability of rice straw. Asian-Aust. J. Anim. Sci., 16: 368-373.

Getachew, G., M. Blummel, H.P.S. Makkar and K. Becker, 1998. In vitro gas measuring techniques for assessment of nutritional quality of feeds: A reveiw. Anim. Feed Sci. Technol., 72: 261-281.

Hart, F.J. and M. Wanapat, 1992. Physiology of digestion of urea-treated rice straw in swamp buffalo. AsianAust. J. Anim. Sci., 5: 61 7-622.

Kennedy, P.M., J.B. Lowry and L.L. Conlan, 1999. Isolation of grass cell walls as neutral detergent fiber increases their fermentability for rumen micro-organisms. J. Sci. Food Agric., 79: 544-548.

Klopferstein, T., 1978. Chemical treatment of crop residues. J. Anim. Sci., 46: 841-848.

Liu, D., J.X. Liu, S.L. Zhu, X.J. Chen and Y.M. Wu, 2005. Histological investigation of tissues and cell wall of rice straw influenced by pretreatment with different chemicals and rumen degradation. J. Anim. Feed Sci., 14: 373-387.

Liu, J.X., A. Susenbeth and K.H. Sudekum, 2002. In vitro gas production measurements to evaluate interaction between untreated and chemically treated rice straws, grass hay and mulberry leaves. J. Anim. Sci., 80: $517-524$.

Liu, J.X., Y.M. Wu and N.Y. Xu, 1995. Effects of ammonia bicarbonate treatment on kinetics of fibre digestion, nutrient digestibility and nitrogen utilization of rice straw by sheep. Anim. Feed Sci. Technol., 52: 131-139.

McDonald, I., 1981. A revised model for the estimation of protein degradability in the rumen. J. Agric. Sci., 96: 251-252.

Menke, K.H. and H. Steingass, 1988. Estimation of the energetic feed value obtained from chemical analysis and gas production using rumen fluid. Anim. Res. Dev., 28: 7-55.

Nicholson, M.J., C.S. McSweeney, R.I. Mackie, J.L. Brookman and M.K. Theodorou, 2010. Diversity of anaerobic gut fungal populations analysed using ribosomal ITS1 sequences in faeces of wild and domesticated herbivores. Anaerobe, 16: 66-73.

Orskov, E.R. and I. McDonald, 1979. The estimation of protein degradability in the rumen from incubation measurements weighted according to rate of passage. J. Agric. Sci., 92: 499-503.

Orskov, E.R., 1994. Recent advances in understanding of microbial transformation in ruminants. Livest. Product. Sci., 39: 53-60. 
Orskov, E.R., B.J. Barnes and B.A. Lukins, 1980. A note on the effect of different amounts of $\mathrm{NaOH}$ application on digestibility by cattle of barley, oats, wheat and maize. J. Agric. Sci., 94: 271-273.

SAS, 1998. SAS/STAT User's Guide. Version 6.12, SAS Inst. Inc., Cary, NC., USA.

Samuel, M., S. Sagathewan, J. Thomas and G. Mathen, 1997. An HPLC method for estimation of volatile fatty acids of ruminal fluid. Indian J. Anim. Sci., 69: 805-807.

Tajima, K., R.I. Aminov, T. Nagamine, H. Matsui, M. Nakamura and Y. Benno, 2001. Diet-dependent shifts in the bacterial population of the rumen revealed with real-time PCR. Applied Environ. Microbiol., 67: 2766-2774.

Theodorou, M.K., M. Gill, C. King-Spooner and D.E. Beever, 1990. Enumeration of anaerobic chytridiomycetes as thallus forming units-novel method for quantification of fibrolytic fungal populations from the digestive-tract ecosystem. Applied Environ. Microbiol., 56: 1073-1078.

Theodorou, M.K., S.E. Lowe and A.P.J. Trinci, 1992. Anaerobic Fungi and the Rumen Ecosystem. In: The Fungal Community: Its Organisation and Role in the Ecosystem, Carroll, G.C. and D.T. Wicklow (Eds.). Marcel Dekker Inc., New York, pp: 43-71.

Trach, X.N., M. Mo and C.X. Dan, 2001. Effects of treatment of rice straw with lime and/or urea on responses of growing cattle. Livest. Res. Rural Dev., 13: 5-5.

Trinci, A.P.J., D.R. Davies, K. Gull, M.I. Lawrence, B.B. Nielsen, A. Rickers and M.K. Theodorou, 1994. Anaerobic fungi in herbivorous animals. Mycol. Res., 98: 129-152.

Van Soest, P.J., 2006. Rice straw, the role of silica and treatments to improve quality. Anim. Feed Sci. Technol., 130: 137-171.
Van Soest, P.J., J.B. Robertson and B.A. Lewis, 1991. Methods for dietary fibre, neutral detergent fibre and nonstarch polysaccharides in relation to animal nutrition. J. Dairy Sci., 74: 3583-3597.

Wanapat, M. and A. Cherdthong, 2009. Use of real-time PCR technique in studying rumen cellulolytic bacteria population as affected by level of roughage in Swamp buffalo. Curr. Microbiol., 58: 294-299.

Wanapat, M., 1999. Feeding of Ruminants in the Tropics Based on Local Feed Resources. Khon Kaen Publishing Company Ltd., Thailand, ISBN-10: 9746766198, pp: 236.

Wanapat, M., F. Sunstol and J.M.R. Hall, 1986. A comparison of alkali treatment method to improve the nutritive value of straw II. In sacco and in vitro degradation relative to in vivo digestibility. Anim. Feed Sci. Technol., 14: 215-220.

Wanapat, M., F. Sunstol and T.H. Germo, 1985. A comparison of alkali treatment method to improve the nutritive value of straw I. digestibility and metabolizability. Anim. Feed Sci. Technol., 12: 295-309.

Wanapat, M., S. Polyorach, K. Boonnop, C. Mapato and A. Cherdthong, 2009. Effect of treating rice straw with urea or urea and calcium hydroxide upon intake, digestibility, rumen fermentation and milk yield of dairy cows. Livest. Sci., 125: 238-243.

Wang, J.K., J.X. Liu, J.Y. Li, Y.M. Wu and J.A. Ye, 2007. Histological and rumen degradation changes of rice straw stem epidermis as influenced by chemical pretreatment. Anim. Feed Sci. Technol., 136: 51-62.

Wilman, D., G.R. Foulkes and D.I. Givens, 1996. A comparison of four methods of estimating the rate and extent of cell wall degradation in grass silages. Anim. Feed Sci. Technol., 63: 99-109.

$\mathrm{Yu}, \mathrm{Z}$. and M. Morrison, 2004. Improved extraction of PCR-quality community DNA from digesta and fecal samples. Biotechniques, 36: 808-812. 